\title{
PENGEMBANGAN BAHAN AJAR KONTEKSTUAL UNTUK MATA PELAJARAN IPS SEKOLAH DASAR
}

\author{
Citra Dwi Lestari \\ Email : citradwi28@gmail.com \\ PGSD FIP Universitas Negeri Jakarta
}

Jl. Setiabudi No. 1 Kelurahan Setiabudi Jakarta Selatan

\begin{abstract}
Abstrak: Penelitian dan pengembangan ini bertujuan untuk menghasilkan produk bahan ajar IPS berbasis pendekatan kontekstual untuk siswa kelas IV Sekolah Dasar. Bahan ajar berisikan materi mengenai kegiatan ekonomi yang berkaitan dengan sumber daya alam dan potensi lain di daerah. Metode yang digunakan pada penelitian ini adalah metode penelitian Research and Development ( $R$ \& D) dengan mengacu pada Model Pengembangan Instruksional dari Atwi Suparman. Penelitian ini dilakukan November 2015 sampai Juni 2016 dan melibatkan siswa kelas empat SDN Binong V Kabupaten Tangerang. Penelitian ini menggunakan angket, observasi, dan wawancara melalui tahapan uji coba ahli, evaluasi satu-satu, evaluasi kelompok kecil, dan uji lapangan. Hasil penelitian menunjukkan, pengembangan bahan ajar IPS berbasis pendekatan kontekstual mencapai hasil dengan kriteria sangat baik.

Kata-kata Kunci: bahan ajar, pendekatan kontekstual, IPS.
\end{abstract}

\section{DEVELOPMENT CONTEXTUAL LEARNING MATERIALS FOR SOCIAL SCIENCE IN ELEMENTARY SCHOOL}

\begin{abstract}
This research and development aimed at producing social science learning materials for the fourth grade of Elementary School students. The learning materials contain economic activities related to natural resources and other potentials in their area. This research used research and development method with reference to the instructional development model adopted by Atwi Suparman. This research involved the fourth grade students in Binong $V$ Primary School, Tangerang Regency. This research used questionnair, observation, and interview to collect data from the respondent. The steps included experts review, one to one evaluation, small group evaluation, and field test. The results indicate that the development of social science learning materials based on contextual approach reach the very good criteria.
\end{abstract}

Keywords: learning materials, contextual approach, social science.

\section{PENDAHULUAN}

Seluruh manusia di dunia membutuhkan pendidikan. Pendidikan merupakan jalan utama untuk membuka cakrawala berpikir manusia. Berpikir adalah daya yang paling utama dan merupakan ciri yang khas yang membedakan manusia dari hewan. Melalui pendidikan, manusia dapat mengembangkan cara berpikir, bersikap, dan potensi diri sehingga dapat mewujudkan kehidupan yang lebih baik pada masa sekarang dan masa yang akan datang.

Menurut Undang-undang No. 20 Tahun
2003 pasal 1 tentang Sistem Pendidikan Nasional, menyatakan bahwa: Pendidikan adalah usaha sadar dan terencana untuk mewujudkan suasana belajar dan proses pembelajaran agar peserta didik secara aktif mengembangkan potensi dirinya untuk memiliki kekuatan spiritual, keagamaan, pengendalian diri, kepribadian kecerdasan, akhlak mulia serta keterampilan yang diperlukan dirinya, masyarakat, bangsa dan Negara.

Terkait dengan peran penting pendidikan di atas, maka kualitas pendidikan merupakan hal penting yang harus diperhatikan. Pendidikan di 
Indonesia sampai saat ini masih jauh dari apa yang diharapkan, contohnya pendidikan pada jenjang sekolah dasar. Rendahnya kualitas pendidikan pada sekolah dasar dapat disebabkan oleh berbagai faktor diantaranya karena proses kegiatan belajar mengajar di sekolah dasar yang pada umumnya masih monoton, pembelajaran dilaksanakan cenderung berpusat pada guru yang akan menyebabkan pembelajaran pasif. Penggunaan bahan ajar masih bergantung pada bahan ajar tinggal pakai dan tinggal beli, padahal bahan ajar merupakan salah satu aspek penting dalam penyampaian pelajaran.

Setiap mata pelajaran di sekolah dasar tentu memerlukan bahan ajar, termasuk mata pelajaran IPS. Melalui mata pelajaran IPS siswa diajak untuk dapat mengenal lingkungan fisik dan lingkungan sosial beserta hubungan dan interaksi yang terjadi antara kedua lingkungan tersebut. Dengan demikian, IPS merupakan salah satu mata pelajaran yang menarik untuk dipelajari karena secara umum IPS memuat hal yang dekat dengan kehidupan siswa. Namun sayangnya, banyak siswa sekolah dasar yang merasa kurang tertarik dalam mempelajari IPS, salah satu penyebabnya adalah karena bahan ajar IPS yang digunakan selama ini belum dapat menimbulkan minat belajar siswa.

Masalah di atas jelas ditemukan peneliti di lingkungan sekolah, yakni di kelas IV SDN Binong V Kec. Curug, Kab. Tangerang-Banten. Bahan ajar yang digunakan adalah berupa buku LKS IPS. Kurang tertariknya siswa kelas IV dengan pelajaran IPS dan bahan ajar yang ada dapat terlihat saat pelajaran IPS berlangsung, siswa terlihat tidak bersemangat ketika mengikuti pelajaran IPS. Siswa terlihat sibuk dengan kegiatannya masing-masing, bercanda bersama teman, dan tidak membaca bahan ajar yang ada.

Berdasarkan hasil wawancara dengan guru kelas IV SDN Binong V, didapatkan informasi bahwa bahan ajar IPS yang digunakan dirasakan belum dapat mendukung proses pembelajaran. Beberapa faktor penyebabnya adalah karena penyajian materi pada bahan ajar cenderung membosankan jika dibaca oleh siswa, karena hanya berisi tulisan atau penjelasan yang padat dan panjang, materi tidak didukung dengan kelengkapan gambar penjelas materi, walaupun terdapat beberapa gambar, namun gambar tersebut tidak berwarna. Selain itu, fasilitas buku untuk menunjang pembelajaran IPS yang tersedia di perpustakaan sekolah juga belum lengkap. Faktor-faktor yang telah diuraikan tersebut menyebabkan siswa mengalami kesulitan di dalam mempelajari IPS.
Pada beberapa kompetensi dasar IPS di kelas IV sd mencakup pembahasan materi yang cukup luas untuk dipelajari. Menurut guru kelas IV salah satu materi yang cukup luas untuk dipelajari adalah pada KD. 2.1 Mengenal aktivitas ekonomi yang berkaitan dengan sumber daya alam dan potensi lain di daerahnya. Kompetensi dasar tersebut terdapat di semester II KTSP 2006. Cukup luasnya materi untuk dipelajari tersebut tidak di dukung dengan kelengkapan penyajian materi di dalam bahan ajar seperti yang telah dijabarkan sebelumnya.

Kekurangan lain yang peneliti temukan dalam bahan ajar yang digunakan adalah tidak terdapatnya tujuan belajar yang harus dikuasai siswa, penggunaan bahasa juga kurang komunikatif, serta penyajian materi dalam bahan ajar tersebut tidak dihubungkan dengan konteks kehidupan nyata siswa, sehingga pembelajaran menjadi kurang bermakna. Untuk itu pemilihan bahan ajar yang tepat diperlukan dalam penyajian materi pada KD. 2.1 tersebut.

Berdasarkan masalah yang telah diuraikan sebelumnya maka diperlukan suatu pengembangan bahan ajar yang dapat menarik minat siswa untuk mempelajarinya dan memudahkan siswa dalam belajar. Penyajian materi dalam bahan ajar disajikan dengan penjelasan yang lebih mudah dimengerti, penggunaan bahasa yang lebih komunikatif, gambar penjelas materi yang lebih lengkap dan berwarna, serta pengaitan antara materi pelajaran dengan tujuan pembelajaran dan kehidupan siswa.

Menurut Barbara B. Seels dan Rita Richey dalam Warsita, pengembangan adalah proses penerjemahan spesifikasi desain ke dalam bentuk fisik. Trianto menyatakan bahwa pengembangan merupakan suatu kegiatan yang dapat berupa perancangan, perencanaan, atau perekayasaan yang dilakukan dengan berdasar metode berpikir ilmiah guna memecahkan permasalahan yang nyata terjadi, sehingga hasil kerja pengembangan berupa pengetahuan ilmiah atau teknologi yang digunakan untuk memecahkan masalah tersebut. Pembelajaran dapat dikatakan berjalan dengan baik apabila tujuan pembelajaran tercapai. Agar tercapainya tujuan pembelajaran yang diinginkan maka dibutuhkan sebuah bahan ajar. Menurut Pannen dalam Prastowo, menyatakan bahwa bahan ajar adalah bahan-bahan atau materi pelajaran yang disusun secara sistematis, yang digunakan guru dan peserta didik dalam proses pembelajaran.

Selanjutnya, Prastowo menyatakan bahwa bahan ajar merupakan sebuah susunan atas bahanbahan yang berhasil dikumpulkan dan berasal dari 
berbagai sumber belajar yang dibuat sistematis. Menurut Widodo dan Jasmadi dalam Lestari, menyatakan bahwa bahan ajar adalah seperangkat sarana atau alat pembelajaran, metode, batasanbatasan, dan cara mengevaluasi yang di desain secara sistematis dan menarik dalam rangka mencapai tujuan yang diharapkan, yaitu mencapai kompetensi atau subkompetensi dengan segala kompleksitasnya.

Pada pembuatan bahan ajar pemilihan warna diperhatikan agar sesuai dengan pengguna bahan ajar. Menurut Hurlock menyatakan bahwa, anak kecil menyukai warna yang cerah dan menyolok dan menganggap warna pastel jelek. Dengan demikian, dalam pengembangan bahan ajar maka pemilihan warna-warna yang cerah dan mencolok seperti warna kuning, merah, biru dan hijau akan lebih diutamakan di dalam desain bahan ajar. Hal ini disesuaikan dengan psikologi pengguna bahan ajar, yakni siswa sekolah dasar kelas IV yang rata-rata berusia 9-10 tahun.

Menurut Sapriya, IPS merupakan nama mata pelajaran di tingkat sekolah dasar dan menengah atau nama program studi di perguruan tinggi yang identik dengan istilah "social studies" dalam kurikulum persekolahan di Negara lain, khususnya di Negara-negara Barat seperti Australia dan Amerika Serikat. Menurut Ahmadi dan Amri, IPS merupakan salah satu mata pelajaran yang diberikan di SD yang mengkaji seperangkat perisitiwa, fakta, konsep, dan generalisasi yang berkaitan dengan isu sosial. Menurut Gunawan, menyatakan bahwa Ilmu Pengetahuan Sosial (IPS) mengkaji seperangkat peristiwa, fakta, konsep, dan generalisasi yang berkaitan dengan ilmu sosial.

Bahan ajar yang sesuai untuk dikembangkan dalam materi ini adalah bahan ajar yang berbasis pendekatan kontekstual. Peneliti mengembangkan bahan ajar dengan pendekatan kontekstual dikarenakan pendekatan tersebut dianggap tepat digunakan dalam pembelajaran IPS terutama dalam materi aktivitas ekonomi yang berkaitan dengan sumber daya alam dan potensi lain di daerahnya. Melalui penggunaan pendekatan kontekstual dalam bahan ajar yang dikembangkan maka akan membuat siswa dapat membuat keterkaitan antara materi pelajaran dengan situasi atau keadaan di dunia nyata.

Rosalin menyatakan bahwa pembelajaran dalam pendekatan kontekstual (CTL) merupakan konsep belajar yang membantu guru mengaitkan antara materi yang diajarkan dan situasi dunia nyata siswa dengan mendorong siswa membuat hubungan antara pengetahuan yang dimilikinya dengan penerapannya dalam kehidupan mereka sebagai anggota keluarga dan masyarakat. Selanjutnya menurut Komalasari, pendekatan kontekstual adalah pembelajaran yang mengaitkan antara materi yang dipelajari dengan kehidupan nyata siswa seharihari, baik dalam lingkungan keluarga, sekolah, masyarakat maupun warga Negara, dengan tujuan untuk menemukan makna materi tersebut bagi kehidupannya. Pendekatan kontekstual dalam pembelajaran menurut Sardiman memiliki langkahlangkah penerapan yang terdiri atas tujuh aspek yaitu, (a) Teori Konstruktivisme, (b) Menemukan (Inkuiri), (c) Bertanya, (d) Masyarakat Belajar (Learning Community), (e) Pemodelan, (f) Refleksi dan Penilaian yang Autentik.

Berdasarkan uraian yang telah dijabarkan sebelumnya, maka perlu dilakukan penelitian pengembangan yang berjudul "Pengembangan Bahan Ajar IPS Berbasis Pendekatan Kontekstual Untuk Siswa Kelas IV SD." Peneliti berharap bahan ajar ini dapat menjadi bahan ajar yang efektif, menyenangkan, dan bermakna dalam pembelajaran IPS khususnya di kelas IV sekolah dasar.

Berdasarkan latar belakang masalah maka fokus pengembangan adalah "Bagaimana mengembangkan bahan ajar IPS berbasis pendekatan kontekstual untuk siswa kelas IV SD?" Penelitian dan pengembangan ini bertujuan untuk menghasilkan sebuah produk bahan ajar pembelajaran IPS untuk siswa kelas IV sekolah dasar. Oleh karena itu, diharapkan dapat memberikan manfaat baik secara teoritis maupun secara praktis.

\section{METODE PENELITIAN}

Metode penelitian yang digunakan adalah metode penelitian dan pengembangan (Research and Development) dengan menggunakan Model Pengembangan Instruksional (MPI) dari Atwi Suparman.

Penelitian pengembangan ini dilaksanakan pada semester dua tahun ajaran 2015/2016 pada bulan November 2015 sampai Juni 2016 di SDN Binong V Kecamatan Curug, Kabupaten Tangerang-Banten.

Teknik analisis data yang digunakan adalah statistik deskriptif kuantitatif. Evaluasi data yang dilakukan adalah evaluasi formatif yang dilakukan dalam empat tahap, yaitu: evaluasi oleh ahli (expert review) yang terdiri atas ahli materi, bahasa, dan media; evaluasi satu-satu (one-to-one evaluation); evaluasi kelompok kecil (small group evaluation); dan uji coba lapangan (field test). Responden dalam penelitian 
pengembangan ini adalah siswa kelas IV SDN Binong V Kecamatan Curug, Kabupaten Tangerang-Banten. Penelitian pengembangan ini dilaksanakan pada semester dua tahun ajaran 2015/2016 pada bulan November 2015 sampai Juni 2016.

\section{HASIL DAN PEMBAHASAN}

Penelitian pengembangan ini menghasilkan sebuah produk bahan ajar IPS berbasis pendekatan kontekstual untuk kelas IV sekolah dasar. Produk bahan ajar berbasis pendekatan kontekstual memuat KD 2.1 Mengenal aktivitas ekonomi yang berkaitan dengan sumber daya alam dan potensi lain di daerahnya.

Produk bahan ajar yang dikembangkan merupakan bahan ajar cetak (printed). Ukuran bahan ajar mengacu pada standar ukuran kertas yang telah ditetapkan oleh ISO untuk kelas IV sekolah dasar yakni A4 (210 x 297 mm). Jenis kertas yang digunakan untuk cover adalah Art Cartoon dengan berat 250 gsm dan untuk isi bahan ajar menggunakan HVS ukuran A4 dengan berat kertas 100 gsm. Jenis huruf yang digunakan dalam bahan ajar adalah Comic Sans MS dengan ukuran huruf 12 pt-14 pt.

Selanjutnya, dilakukan tahap expert review, produk bahan ajar dinilai berdasarkan instrumen yang telah dibuat. Tabel 1 berikut merupakan penilaian ahli materi berdasarkan instrumen yang digunakan dengan rekapitulasi.

Tabel 1. Hasil Rekapitulasi Ahli Materi

\begin{tabular}{llcccc}
\hline No. & Aspek yang dinilai & $\begin{array}{c}\text { Jumlah } \\
\text { Butir }\end{array}$ & $\begin{array}{c}\text { Skor } \\
\text { Kriterium }\end{array}$ & $\begin{array}{c}\text { Jumlah } \\
\text { Nilai }\end{array}$ & $\%$ \\
\hline 1. & $\begin{array}{l}\text { Kesesuaian uraian } \\
\text { materi dengan SK } \\
\text { dan KD }\end{array}$ & 5 & 20 & 18 & \\
2. & Keakuratan materi & 3 & 12 & 10 & 18 \\
3. & $\begin{array}{l}\text { Materi pendukung } \\
\text { pembelajaran }\end{array}$ & 5 & 20 & 27 & \\
4. & $\begin{array}{l}\text { Langkah-langkah } \\
\text { pendekatan }\end{array}$ & 7 & 28 & & \\
$\quad$ kontekstual & Jumlah & 20 & 80 & 73 & 91,25 \\
\hline
\end{tabular}

Berdasarkan hasil rekapitulasi ahli materi pada tabel 1, dapat terlihat bahwa produk bahan ajar mendapatkan persentase penilaian oleh ahli materi sebesar 91,25\% maka dapat dikategorikan sangat baik. Selanjutnya, Tabel 2 berikut merupakan hasil rekapitulasi penilaian oleh ahli bahasa.
Tabel 2. Hasil Rekapitulasi Ahli Bahasa

\begin{tabular}{llccc}
\hline No. & Aspek yang dinilai & $\begin{array}{c}\text { Jumlah } \\
\text { Butir }\end{array}$ & $\begin{array}{c}\text { Skor } \\
\text { Kriterium }\end{array}$ & $\begin{array}{c}\text { Jumlah } \\
\text { Nilai }\end{array}$
\end{tabular}

Berdasarkan data pada tabel 2 di atas dapat terlihat bahwa produk bahan ajar mendapatkan persentase penilaian oleh ahli bahasa sebesar 90,62\% maka dapat dikategorikan sangat baik.

Selanjutnya, Tabel 3 berikut merupakan hasil rekapitulasi penilaian oleh ahli media.

Tabel 3. Hasil Rekapitulasi Ahli Media

\begin{tabular}{llcccc}
\hline No. & Aspek yang dinilai & $\begin{array}{c}\text { Jumlah } \\
\text { Butir }\end{array}$ & $\begin{array}{c}\text { Skor } \\
\text { Kriterium }\end{array}$ & $\begin{array}{c}\text { Jumlah } \\
\text { Nilai }\end{array}$ & $\%$ \\
\hline 1. & Teknik penyajian & 3 & 12 & 11 & \\
2. & $\begin{array}{l}\text { Penyajian } \\
\text { pembelajaran }\end{array}$ & 3 & 12 & 11 & \\
3. & $\begin{array}{l}\text { Kelengkapan } \\
\text { penyajian }\end{array}$ & 10 & 40 & 40 & \\
4. & $\begin{array}{l}\text { Ukuran bahan ajar } \\
\text { 5. }\end{array}$ & 2 & 8 & 8 & \\
$\quad \begin{array}{l}\text { Desain kulit bahan } \\
\text { ajar }\end{array}$ & 10 & 40 & 40 & \\
6. & $\begin{array}{l}\text { Desain isi bahan } \\
\text { ajar }\end{array}$ & 14 & 56 & 54 & \\
\hline & $\quad$ Jumlah & 42 & 168 & 164 & 97,6 \\
\hline
\end{tabular}

Berdasarkan data pada tabel 3 di atas dapat terlihat bahwa produk bahan ajar mendapatkan persentase penilaian oleh ahli media sebesar 97,6\% maka dapat dikategorikan sangat baik. Komentar dan saran dari para ahli peneliti gunakan untuk memperbaiki produk bahan ajar.

Selanjutnya penelitian dilanjutkan pada tahap evaluasi formatif yakni evaluasi satu-satu (one to one evaluation) dengan melibatkan tiga orang siswa 
kelas IV B SDN Binong V sebagai responden. Tabel 4 berikut adalah hasil rekapitulasi one to one evaluation.

Tabel 4. Hasil Rekapitulasi One-to-one Evaluation

\begin{tabular}{ccccc}
\hline No & Responden & $\begin{array}{c}\text { Jumlah } \\
\text { Butir Soal }\end{array}$ & $\begin{array}{c}\text { Jumlah } \\
\text { Skor }\end{array}$ & Persentase (\%) \\
\hline 1 & IS & 9 & 8 & 88,89 \\
2 & MIM & 9 & 9 & 100 \\
3 & SH & 9 & 9 & 100 \\
\hline \multicolumn{5}{c}{ Rata-rata } \\
\hline
\end{tabular}

Berdasarkan data pada tabel 4, dapat terlihat bahwa produk bahan ajar mendapatkan persentase penilaian pada tahap one-to-one evaluation sebesar 96,3\% maka dapat diartikan bahwa produk bahan ajar menurut responden sangat baik.

Setelah melalui tahap one to one evaluation selanjutnya dilakukan penelitian tahap small group evaluation dengan melibatkan sepuluh orang siswa kelas IV B SDN Binong V sebagai responden. Tabel 5 berikut adalah hasil rekapitulasi small group evaluation.

Tabel 5. Hasil Rekapitulasi Small Group Evaluation

\begin{tabular}{ccccc}
\hline No & Responden & $\begin{array}{c}\text { Jumlah } \\
\text { Butir Soal }\end{array}$ & $\begin{array}{c}\text { Jumlah } \\
\text { Skor }\end{array}$ & Persentase (\%) \\
\hline 1 & AW & 17 & 16 & 94,12 \\
2 & DM & 17 & 17 & 100 \\
3 & IS & 17 & 16 & 94,12 \\
4 & LR & 17 & 17 & 100 \\
5 & MA & 17 & 17 & 100 \\
6 & MI & 17 & 15 & 88,24 \\
7 & MRB & 17 & 16 & 94.12 \\
8 & NAZ & 17 & 17 & 100 \\
9 & NF & 17 & 17 & 100 \\
10 & SSS & 17 & 17 & 100 \\
\hline \multicolumn{5}{c}{ Rata-rata } \\
\hline
\end{tabular}

Berdasarkan data pada tabel 5 di atas, dapat terlihat bahwa produk bahan ajar mendapatkan persentase penilaian pada tahap small group evaluation sebesar $97.06 \%$ maka dapat diartikan bahwa produk bahan ajar yang menurut responden sangat baik.

Setelah melalui tahap small group evaluation selanjutnya dilakukan penelitian tahap terakhir yakni field test dengan melibatkan siswa kelas IV A SDN Binong V sebagai responden. Tabel 6 berikut adalah hasil rekapitulasi field test.
Tabel 6. Hasil Rekapitulasi Field Test

\begin{tabular}{|c|c|c|c|c|}
\hline No & Responden & $\begin{array}{l}\text { Jumlah } \\
\text { Butir Soal }\end{array}$ & $\begin{array}{l}\text { Jumlah } \\
\text { Skor }\end{array}$ & Persentase (\%) \\
\hline 1 & $\mathrm{AD}$ & 17 & 14 & 82,35 \\
\hline 2 & $\mathrm{AF}$ & 17 & 17 & 100 \\
\hline 3 & AHK & 17 & 14 & 82,35 \\
\hline 4 & $\mathrm{AR}$ & 17 & 17 & 100 \\
\hline 5 & AN & 17 & 17 & 100 \\
\hline 6 & AA & 17 & 17 & 100 \\
\hline 7 & AND & 17 & 17 & 100 \\
\hline 8 & $\mathrm{APH}$ & 17 & 16 & 94,12 \\
\hline 9 & BMW & 17 & 16 & 94,12 \\
\hline 10 & $\mathrm{BH}$ & 17 & 17 & 100 \\
\hline 11 & CAR & 17 & 17 & 100 \\
\hline 12 & EA & 17 & 17 & 100 \\
\hline 13 & FRS & 17 & 15 & 88,24 \\
\hline 14 & KM & 17 & 17 & 100 \\
\hline 15 & $\mathrm{MM}$ & 17 & 16 & 94,12 \\
\hline 20 & RFR & 17 & 16 & 94,12 \\
\hline 21 & RAS & 17 & 17 & 100 \\
\hline 22 & RTW & 17 & 16 & 94,12 \\
\hline 23 & $\mathrm{RP}$ & 17 & 17 & 100 \\
\hline 24 & $\mathrm{RH}$ & 17 & 14 & 82,35 \\
\hline 25 & SI & 17 & 17 & 100 \\
\hline 26 & $\mathrm{SN}$ & 17 & 17 & 100 \\
\hline 27 & SS & 17 & 17 & 100 \\
\hline 28 & WTA & 17 & 17 & 100 \\
\hline \multicolumn{4}{|c|}{ Rata-rata } & 96.64 \\
\hline
\end{tabular}

Berdasarkan data pada Tabel 6 di atas, dapat terlihat bahwa produk bahan ajar berbasis pendekatan konterkstual mendapatkan persentase penilaian pada tahap field test sebesar $96.64 \%$. Sesuai persentase yang didapatkan maka dapat diartikan bahwa produk bahan ajar yang menurut responden sangat baik.

Berdasarkan hasil penelitian tersebut, pengembangan bahan ajar ini dapat digunakan secara mandiri atau digunakan untuk siswa belajar di rumah dan di sekolah. Selain untuk siswa, produk ini juga dapat menjadi alternatif bahan ajar yang dapat digunakan oleh guru untuk kegiatan belajar tatap muka pada materi KD. 21 Mengenal aktivitas ekonomi berdasarkan sumber daya alam dan potensi lain di daerah.

Melalui penggunaan pendekatan kontekstual sebagai basis pada bahan ajar, maka dapat menciptakan pembelajaran yang lebih bermakna karena siswa dapat menghubungkan antara materi yang dipelajari dengan kehidupan sehari-hari. 
Kegiatan belajar juga dapat dilaksanakan dengan lebih menyenangkan karena siswa dapat terlibat aktif di saat proses kegiatan belajar berlangsung.

Di dalam penggunaan produk bahan ajar, sebaiknya guru juga memperhatikan beberapa hal lain sehingga dapat menciptakan pembelajaran yang maksimal. Hal tersebut seperti penguasan materi yang baik oleh guru, penguasaan penerapan langkahlangkah pendekatan kontekstual, penggunaan media pembelajaran yang dapat mendukung proses pembelajaran, dan pemanfaatan berbagai sumber belajar yang berada di sekitar siswa.

\section{PENUTUP}

\section{Kesimpulan}

Penelitian dan pengembangan ini menghasilkan produk bahan ajar IPS untuk siswa kelas IV sekolah dasar dengan judul "Mengenal Kegiatan Ekonomi". Pengembangan bahan ajar dilakukan karena bahan ajar yang sebelumnya digunakan di sekolah yakni LKS dirasakan belum memadai dan belum sesuai kebutuhan siswa. Bahan ajar dibuat dengan berbasis pendekatan kontekstual. Dengan pendekatan kontekstual maka kegiatan belajar yang dilakukan akan lebih bermakna karena siswa dapat membuat keterkaitan antara materi pelajaran dengan situasi atau keadaan di dunia nyata. Peneliti mengembangkan bahan ajar IPS berbasis pendekatan kontekstual mengacu dan mengikuti langkahlangkah dari model pengembangan instruksional menurut Atwi Suparman.

Di dalam proses pengembangan, bahan ajar IPS berbasis pendekatan kontekstual yang dikembangkan diuji validitas oleh 3 orang ahli, yaitu ahli materi, ahli bahasa, dan ahli media. Hasil rata-rata persentase penilaian dari para ahli secara keseluruhan mencapai 93.16\% dengan demikian produk dinyatakan valid dengan kriteria sangat baik. Selanjutnya dilakukan tahap uji coba pada siswa kelas IV SDN Binong $\mathrm{V}$ Kabupaten Tangerang. Pertama, tahap one to one evaluation didapatkan hasil rata-rata mencapai 96,3\% dengan kriteria sangat baik. Kedua, yakni tahap small group evaluation didapatkan hasil rata-rata mencapai 97,06\% dengan kriteria sangat baik. Terakhir adalah tahap field test didapatkan hasil rata-rata mencapai 96,64\% dengan kriteria sangat baik.

Hasil observasi tahap small group evaluation dan tahap field test menunjukkan bahwa bahan ajar dapat digunakan secara efektif dan tidak melebihi waktu yang dialokasikan untuk pelajaran IPS (2x35 menit). Guru dan siswa terlihat tidak mengalami kesulitan disaat kegiatan belajar berlangsung. Pada saat wawancara guru menyatakan ketertarikannya menggunakan produk bahan ajar di dalam kegiatan belajar di kelas.

Berdasarkan penjabaran di atas, maka dapat disimpulkan bahwa hasil pengembangan bahan ajar IPS berbasis pendekatan kontekstual untuk kelas IV sekolah dasar ini merupakan produk yang valid dan sudah mencapai kriteria sangat baik. Produk ini dapat digunakan sebagai bahan ajar IPS di kelas IV pada materi mengenal aktivitas ekonomi berdasarkan sumber daya alam dan potensi lain di daerah yang tertera pada kompetensi dasar 2.1 KTSP 2006.

\section{Saran}

Peneliti memberikan saran sebagai berikut: Siswa diharapkan menggunakan bahan ajar berbasis pendekatan kontekstual sebagai sumber belajar sehingga siswa dapat melakukan kegiatan belajar yang bermakna dan menyenangkan, Guru diharapkan dapat menggunakan bahan ajar berbasis pendekatan kontekstual dengan materi mengenai kegiatan ekonomi yang berkaitan dengan sumber daya alam dan potensi lain sebagai bahan ajar alternatif yang dapat memberikan pemahaman mengenai kegiatan ekonomi, sekolah diharapkan dapat memanfaatkan bahan ajar ini sebagai tambahan koleksi bahan ajar IPS dan menjadi salah satu sumber belajar alternatif yang dapat digunakan secara maksimal di dalam pembelajaran di kelas, dan peneliti selanjutnya diharapkan dapat menghasilkan produk bahan ajar yang lebih baik dan inovatif serta dapat mengembangkan materi pada kompetensi dasar dan materi selanjutnya.

\section{DAFTAR PUSTAKA}

Ahmadi, L. K.,\& Amri, S. (2011). Mengembangkan pembelajaran IPS terpadu. Jakarta: Prestasi Pustakarya.

Amri, S.,\& Ahmadi, L. K. (2010). Konstruksi pengembangan pembelajaran. Jakarta: PT. Prestasi Pustakarya.

Emzir. (2014). Metodologi penelitian pendidikan. Depok: Rajagrafindo Persada.

Gunawan, R. (2014). Pengembangan kompetensi guru IPS. Bandung: ALFABETA.

Hindarto, M. P. (2006). Warna untuk desain interior. Yogyakarta: Media Pressindo.

Hurlock, E. B. (1978). Perkembangan anak jilid 2. Jakarta : Erlangga.

Iskandarwassid.,\& Sunendar, D. (2009). Strategi pembelajaran bahasa. Bandung: Remaja 
Rosdakarya.

Kementrian Pendidikan Nasional. (2011). Standar kompetensi dan kompetensi dasar sekolah dasar/ madrasah ibtidaiyah. Jakarta: Kementrian Pendidikan Nasional.

Komalasari, K. (2013). Pembelajaran kontekstual konsep dan aplikasi. Bandung: Refika Aditama.

Lestari, I. (2013). Pengembangan bahan ajar berbasis kompetensi. Padang: Akademia Permata.

Maryani, E. (2011). Pengembangan program pembelajaran IPS untuk meningkatkan keterampilan sosial. Bandung: Alfabeta.

Muclish, M. (2009). KTSP pembelajaran berbasis kompetensi dan kontekstual. Jakarta: Bumi Aksara.

Muclish, M. (2010). Text book writing. Jogjakarta: ArRuzz Media.

Mulyasa, E. (2009). Standar kompetensi dan sertifikasi guru. Bandung: Remaja Rosdakarya.

Prastowo, A. (2011). Panduan kreatif membuat bahan ajar inovatif. Jogjakarta: DIVA Press.

Purwanto, N. (2007). Psikologi pendidikan. Bandung: Remaja Rosdakarya.

Putra, N. (2011). Research E development. Jakarta: RajaGrafindo Persada.

Rosalin, E. (2008). Gagasan merancang pembelajaran kontekstual. Bandung: Karsa Mandiri Persada.

Sanjaya, W. (2013). Perencanaan dan desain sistem pembelajaran. Jakarta: Prenada Media Grup.

Sanjaya, W. (2010). Strategi pembelajaran berorientasi standar proses pendidikan. Jakarta: Kencana.
Sapriya. (2013). Pendidikan IPS. Bandung: Remaja Rosdakarya.

Sitepu, B. P. (2012). Penulisan buku teks pelajaran. Bandung: Remaja Rosdakarya.

Sardiman. (2011). Interaksi \& motivasi belajar mengajar. Jakarta: Raja Grafindo Persada.

Sugiyanto. (2010). Model-model pembelajaran inovatif. Surakarta: Yuma Pustaka.

Sugiyono. (2010). Metode penelitian kuantitatif, kualitatif dan RED. Bandung: Alfabeta.

Suparman, M. A. (2012). Desain Instruksional Modern. Jakarta: Erlangga.

Susanto, A. (2013). Teori belajar pembelajaran di sekolah dasar. Jakarta: Prenamedia Group.

Syaodih, N. S.,\& Syaodih, E. (2012). Kurikulum dan pembelajaran kompetensi. Bandung: Refika Aditama.

Trianto. (2011). Pengantar Penelitian Pendidikan bagi Pengembangan Profesi Pendidikan \& Tenaga Kependidikan. Jakarta: Prenada Media Grup.

Trianto. (2013). Mendesain model pembelajaran inovatifprogresif. Jakarta: Prenada Media Group.

Undang-Undang Republik Indonesia Nomor 18 Tahun 2002. Sistem Nasional Penelitian, Pengembangan, dan Penerapan Ilmu Pengetahuan dan Teknologi. http:/ / www.dpr.go.id/dokjdih/document/ uu/UU_2002_18.pdf. Diakses pada tanggal 9 Desember 2015 pukul 19.16 WIB

Warsita, B. (2008). Teknologi pembelajaran landasan dan aplikasinya. Jakarta: Rineka Cipta. 
Pengembangan Bahan Ajar ...

112 PERSPEKTIF Ilmu Pendidikan - Vol. 30 No.2 Oktober 2016 